\title{
An Assessment of the Role of Credit Reference Bureau in Influencing Customer Credit Access in Mitigating Against Credit Default in Commercial Banks in Kenya
}

\author{
Ruthwinnie Njeri Munene ${ }^{\# 1}$, Dr. Paul Muoki Nzioki ${ }^{\# 2}$, Prof.Tom Nyamache ${ }^{\# 3}$ \\ P.O BOX Private Bag Kabarak
}

\section{ABSTRACT}

The study examined the role of Credit Reference Bureau (CRB) in influencing customer credit access in mitigating default risk among commercial banks in Kenya. The study was based on the theories of Adverse Selection and Hazard. The study used a Causal-Comparative descriptive survey design. The target population of the study consisted of all the 43 licensed commercial banks in Kenya and the three licensed credit reference bureaus in Kenya under the Banking Act. The researcher used a census of all commercial bank headquarters bank managers and the three headquarters credit reference bureau managers. To collect primary data, the researcher used questionnaires. Secondary data were collected from CBK loan books and CBK annual Bank supervisory reports. Data was analysed using SPSS and results presented using graphical systems. The researcher used descriptive statistics, which included the mean, median standard deviation and range to show the default rate. The inferential statistical tests comprised correlation, ANOVA regression and Chi-square analysis to test hypothesis. P -values yielded were less than 0.05, which indicated that the role played by Credit Revenue Bureau in influencing customer access to credit and mitigation of Credit Default Rate was significant among commercial banks in Kenya.

Key words: credit reference bureau, credit, credit access, credit default rate and commercial banks

Corresponding Author: Ruthwinnie Njeri Munene

\section{INTRODUCTION}

Financial institutions are facing an enormous risk of NPLs noting that larger loans have greater risk exposure, so the variable costs per-dollar is higher. If lenders do not take extra care, there could be more loan defaults. CRB enables banks to determine credit worthiness of their borrowers and therefore reducing the loan default risk. In this respect CRB assists in first, sharing information on default among banks; secondly, eliminating corrupt borrowers and thirdly to provide commercial professional credit reference to prospective foreign investors; and also to identify credible borrowers based on known history and character (Bofondi and Gobbi , 2003)

Credit Reference Bureau provides detailed information on a person's credit history, including information on their identity, credit accounts and loans, bankruptcies and late payments and recent inquiries. Other information shared include: proven frauds and forgeries, cheque kiting, false declarations and statements, receiverships, bankruptcies and liquidations, credit default and 
late payments, use of false securities, and misapplication of borrowed funds. Prospective lenders access the information only when they have permissible reason as defined in law, to determine the borrower's creditworthiness (Sullivan \& Sheffrin, 2003). The individual information collected by CRBs is made available on request to customers of the credit bureau for the purposes of credit risk assessment, credit scoring or for other purposes such as employment consideration or leasing an apartment. Generally, CRB enables financial institutions to lend to more and better risky clients and to determine better the bad loans that they need to cover expected losses of credit to good payers. Second, credit bureaus reduce the borrowing cost by forcing creditors to be more competitive for good borrowers. Those lower costs for good credit risks motivate those borrowers to be more careful with repayment. Third, credit bureaus reduce moral hazard by developing a credit culture where they operate as borrowers become aware that credit market becomes aware of their credit history and rewards or punishes them accordingly (Leonard, 1995).

\subsection{Statement of the Problem}

According Ahmad (2007) in spite of the adoption of CRB in Kenya, credit risk is still a major issue in Kenyan banking sector. Kenyan banking sector has been burdened with a momentous NPLs portfolio which is a major root cause of economic distortion and stagnation which needs to be controlled if Kenya has to achieve economic growth and stabilization. In the recent past, CBK has put a number of banks commercial banks on receivership. CBK in the year 2015 placed Dubai Bank of Kenya on receivership due to worsening cash reserve ratio position and failure to settle financial obligations, including kshs 48 million due to Bank of Africa Kenya. Imperial Bank Ltd was placed on receivership in 2016 for facing serious liquidity problems catalyzed by "Serial defaulters" who borrowed from various banks with no intention of repaying the loans.(CBK 2016).In the Kenyan Milieu, few aspects relating to Credit Reference Bureau have been reviewed Al-Khouri (2011).study by Sigei (2010) evaluated the effectiveness of CRB in Kenya, Ng'anga (2011) on the other hand investigated stakeholder perception of credit reference bureau services in the Kenyan credit market. Further, Gaitho (2010) examined the role of credit reference bureau on credit access. There still exist gaps in literature that needs to be filled. Therefore, this study aimed at determining the role of CRBs in influencing customer access to credit in Mitigating against loan default among Commercial banks in Kenya.

\subsection{Objective of the study}

To examine the role of CRB in influencing customer credit access in mitigating against credit default in commercial banks in Kenya.

\subsection{Research Hypothesis}

$\mathbf{H}_{\mathbf{0}}$ : CRB does not have a significant role in influencing customer credit access in mitigating against credit default in commercial banks in Kenya.

$\mathbf{H}_{\mathbf{A}}$ : CRB has a significant role in influencing customer credit access in mitigating against credit default in commercial banks in Kenya. 


\section{LITERATURE REVIEW}

\subsection{Theoretical Review}

Credit Rationing Theory: The theory was introduced by Freimer and Gordon (1965) and comprehensively applied by Stiglitz and Weiss (1981). Stiglitz and Weiss (1981) asymmetric information leads to credit rationing, as lenders cannot distinguish between high quality and low quality borrowers. However, De Reza \& Webb (1987) showed that asymmetric information in credit markets can lead to the inverse result, which is an excess of credit or over lending. For banks to exist they have to screen and monitor borrowers more efficiently than other investors (Allen \& Santomero, 1998). CRBs are specialized in gathering private information about potential loan applicants. In managing money and deposit accounts, banks own strategic information on firms' receipts and expenditures. Nevertheless, banks may suffer from informational asymmetries such that evolution of prices cannot clear the credit market (Diamond \& Rajan, 2011). According to Stiglitz and Weiss (1981), credit rationing occurs if banks charge the same interest rate to all borrowers, because they cannot distinguish between borrowers and screening borrowers perfectly is too expensive. Banks are usually able to distinguish their borrowers up to a certain degree. Banks usually charge more than just one interest rate to all customers. High-risk borrowers pay a higher interest rate and credit rationing is less likely. Since financial institutions cannot distinguish borrowers perfectly and screening them perfectly is impossible, credit rationing may occur.

\subsection{Empirical Review}

The high financial cost of borrowing generally reduces the borrowers' repayment capacity which results in credit risk. If the credit risk can be controlled, it can lead to increased access to credit. This implies that credit risk is a critical source of economic distortion and stagnation which must not only be monitored but also controlled. Maintaining credit accessibility is crucial to the achievement of positive economic results. While financial institutions continue to extend credit facilities, the problem of credit risk becomes a complicated issue requiring continued in-depth research to avoid economic distresses to financial institutions. The prerequisites of an effective credit access include an efficient systems and procedures for credit risk management (Leonard, 1995). Generally, banks may encounter difficulty in meeting obligations from its financial liabilities if they do not maintain appropriate liquidity levels. In the case of banks, the approach to managing liquidity is to ensure, as far as possible, that it will always have sufficient liquidity to meet its liabilities when due, under both normal and stressed conditions, without incurring unacceptable losses or risking damage to the bank's reputation. The bank's treasury maintains a portfolio of short-term liquid assets, largely made up of short-term liquid investment securities, loans and advances to banks and other inter-bank facilities, to ensure that sufficient liquidity is maintained within the Bank as a whole. The daily liquidity position is monitored and regular liquidity stress testing is conducted under a variety of scenarios covering both normal and more severe market conditions. The key measure used by banks for managing liquidity risk is the ratio of net liquid assets to deposits from customers (Auronen, 2003).

Other researchers have recently reviewed the influence of CRB on credit access. For instance Nga'nga (2011) investigated the role of CRB in accessing loans in Kenya. His study revealed that CRBs play an important role in preventing serial loan defaulters from accessing credits from other financial institutions thus cushioning financial institutions against unforeseen credit risks. 
Similar sentiments are also shared by others researchers (Mumi, 2010; Gaitho, 2010 ;). Credit reference bureaus are meant to complement the central role played by banks and other financial institutions in extending financial services within an economy. CRBs help lenders make faster and more accurate credit decisions. They collect, manage and disseminate customer information to lenders within a provided regulatory framework. Credit histories not only provide necessary input for credit underwriting, but also allow borrowers to take their credit history from one financial institution to another, thereby making lending markets more competitive and, in the end, more affordable (Nakulenge, 2003). According to Sinare (2008) credit reporting agencies gather information on the experiences of individuals with credit, leases, non-credit, related bills. Monetary, related public records, and enquiries and compile a credit record. Credit reporting agencies attempt to collect comprehensive information on all lending to individuals in the country in which they operate. Credit Account Information records contain a wide range of details about each account. This information generally falls into five broad categories: account identification, account dates, account balances, account description, and payment performance. Each credit account record includes an account number, a unique identifier for each credit provider, and account ownership status in particular, single or joint account or authorized user. Pertinent date information includes the date the account was established; the date it was closed or transferred to collection or other major change in status; the date the account balance was paid down to zero; and the date when information was last reported to the credit reporting agency. Njuguna (2010) the account records also provide current balance information, the largest amount ever owed on the account, the size of any credit limit applicable to the account and any amount past due.

According to Richard (2011) credit account records include a variety of account descriptive information, including identification of the type of account for example a closed end loan mortgage or installment or open end loan revolving, non-revolving, or cheque credit and the nature or purpose of the account for example credit card, charge account, automobile loan, or student loan. Finally, the credit account record provides information on the extent of current and historical payment delinquencies extending back months as well as information on other account derogatory. Payment delinquency information is recorded in four classes of increasing severity 30 to 59 days, 60 to 89 days, 90 to 119 days, and 120 or more days past due. Other derogatories refer to accounts that have been charged off or are in collection, or those associated with a judgment, bankruptcy, foreclosure or repossession. Typically, accounts that are 120 or more days past due and accounts with other derogatory are grouped together and termed as major derogatory or seriously delinquent. Accounts with less severe delinquencies are typically termed as minor delinquencies addition to personal characteristics and credit account information, credit reporting agency data include information derived from monetary related public records and reports from collection agencies (Kaynak, 2001).

\section{MATERIALS AND METHODS}

\subsection{Research Design and target population}

The study used a Causal-Comparative descriptive survey design. Causal-comparative studies attempt to identify cause effect relationships, involve comparison, and attempts to make inferences without direct intervention. This design was appropriate for this study because comparison allowed for the establishment of conclusive causality attributing observed changes in effectiveness of CRB practices. The researcher employed descriptive statistic analysis and 
methods of analyzing correlations and regressions between multiple variables. The study was carried out in Kenya among the commercial bank at their headquarters and credit reference bureau headquarters in Nairobi County. The target population was composed of all 43 licensed commercial banks in Kenya and the 3 CRBs under the Banking Act (CBK, 2012). All these banks were studied since a conclusive and completely representative analysis was to be arrived at in the end.

\subsection{Sampling Procedures}

The researcher drew the entire sample from the population using census approach. The researcher was confident that the chosen sample was truly representative of the entire population. All credit commercial bank managers at the headquarters and credit reference bureau managers were used for the study. However two commercial banks and one CRB was left out in final study since they were used in pilot testing as shown in table 1

Table 1: Respondent's Categories Sample Size

\begin{tabular}{ll}
\hline Respondent's Categories & Respondents Size \\
\hline Bank Credit managers & 41 \\
Credit Reference Bureau Africa Limited (TransUnion) managers & 1 \\
Metropol Credit Reference Bureau Ltd managers & 1 \\
\hline Total & $\mathbf{4 3}$ \\
\hline
\end{tabular}

\subsection{Research Instrument}

The study collected both primary and secondary data. Primary data was collected using questionnaires. The questionnaires had both open and closed ended items. Besides, secondary data were collected from CBK loan book, CBK annual Bank supervisory reports. The data required was collected for a period of five years before the introduction of CRB and five years. Other sources of secondary data included annual publications, newspapers, journals, monthly publication, and library books were used to form the backbone of literature review. A pilot study was conducted at two of the commercial banks and one CRB .Pilot study is thus conducted to detect weakness in design and instrumentation and to provide accurate data for selection of a sample (Young, 2009). Piloting testing was carried out to ensure validity and reliability of the instrument. Its content was pre-tested by a pilot study carried out Diamond Trust Bank and I \& M banks headquarters in Nairobi. These banks were selected on the bases that they had the lowest credit default between 2010-2015 according to banking sector report (2015). Creditinfo reference bureau limited headquarter in Nairobi was used for pilot study since it was the latest reference bureau to be established in Kenya in 2015. To ensure validity, questionnaire were prepared in conjunction with literature review and based on the research objectives and questions. The questionnaire was discussed with the supervisor, colleagues, experienced researchers and professional bankers. Completed questionnaires were collected directly from respondents that enabled any clarification of any issues. In assessing reliability of the data, internal consistency method using Cronbach's alpha was used. Reliability is the degree to which an instrument measures accurately what it claims to measure. According to Powell, (2004) reliability is always contingent on the degree of uniformity of the given characteristics in the population. 


\subsection{Data Collection and analysis}

With the help of research assistants, the researcher visited the commercial banks and CRBs and administered the questionnaires. Arrangements were made with the assistance of public relations officers to administer questionnaires to the credit managers and CRB management at the headquarters. The researcher acquired a research permit from National Council of Science and Technology (NACOSTI). The researcher also had an introduction letter from Kabarak University. The researcher then administered the questionnaires to the respondents. The researcher sent an email to the respondents in advance explaining the purpose of the study. The questionnaires were delivered to the target respondent by the researcher and research assistant to allow familiarity with the respondent in building the confidence between the researcher and the respondent on the intention of carrying out the study. The questionnaires were picked after two weeks from the date of issuance when a prearranged date was confirmed for collection. On completion of the questionnaires, the researcher organized the data received, coded, edited and tabulated to check accuracy, completeness and storing it in appropriate form. The data was stored in electronic form and paper form for the purpose of data analysis. The data was analyzed using spreadsheet as it has versatile analysis and storage combination tools. Spreadsheet incorporated elements of exploratory data analysis and relevant information from the spreadsheet was copied directly across to a report. The data was presented using graphical systems, which included histograms and pie charts, frequency distributions tables and numerical methods. The data was analyzed in order to make deductions and inferences. Exploratory method was used to analyze qualitative research and confirmatory method was used to analyze quantitative research. Statistical techniques were also used to analyze the data, which measured measures of central tendency that is the mean, the median and the mode. Measures of dispersion were also calculated which included standard deviation. Statistical computing was done using Excel and Statistical Package for Social Sciences (SPSS).

\section{RESULTS AND DISCUSSION}

\subsection{Pilot Study and response rate}

The researcher conducted a pilot study in two banks that are homogeneous in terms of composition and operations with the targeted banks to establish the reliability of the research tools. The results are presented in Table 2

Table 2 Reliability Analysis

\begin{tabular}{lll}
\hline Reliability Statistics & No. of Items & Cronbach's Alpha value \\
\hline Credit access & 19 & 0.783 \\
Credit default rates in commercial banks & 15 & 0.729 \\
\hline
\end{tabular}

A coefficient of above 0.7 was obtained and this indicated that the data collection instruments were valid (Kothari, 2005). An alpha coefficient higher than 0.7 indicates that the gathered data has a relatively high internal consistency and could be generalized to reflect opinions of all respondents in the target population (Mandrish and Schaffer, 2005). The validity of the questionnaires was determined using construct validity method. The instruments were reviewed to improve their validity as well as reliability. 


\begin{tabular}{lcccl}
\hline \hline \multicolumn{2}{l}{ Table 3 Response Rate } & & & \\
\hline Response Category & Frequency & $\begin{array}{c}\text { Response } \\
\text { irequency }\end{array}$ & (\%) & $\begin{array}{l}\text { Non- } \\
\text { Response (\%) }\end{array}$ \\
\hline Unit response & $\mathbf{3 5}$ & 81.39 & 8 & 18.61 \\
Item response & $\mathbf{3 0}$ & 82.27 & 7 & 17.73 \\
\hline Overall Response & & $\mathbf{8 1 . 8 3}$ & & $\mathbf{1 8 . 1 7}$ \\
\hline
\end{tabular}

Table 3 reveals that out of all the 43 data collection tools issued to the respondents, the researcher recovered 35 yielding a unit response rate of $81.39 \%$. For the recovered tools, $82.27 \%$ of the items' response was valid. This study was considered to be a success as data was found to be sufficient for analysis since the overall response rate was $81.83 \%$ according to Babbie (1995) who considers $70 \%$ response rate and above to be very good.

\subsection{Descriptive Analysis}

Table 4: Distribution of Respondents by Department

\begin{tabular}{lll}
\hline Department & Frequency & Percent \\
\hline Operation & 14 & 40.00 \\
Credit & 20 & 57.14 \\
Risk & 1 & 2.86 \\
\hline Total & $\mathbf{3 5}$ & $\mathbf{1 0 0}$ \\
\hline
\end{tabular}

The study focus being on loan default mitigation, majority of the respondents $(57.14 \%)$ were drawn from the credit section of the bank.

Table 5: Credit Access for Financial Institutions

\begin{tabular}{lll}
\hline Credit Facility & Frequency & Percent \\
\hline More accessible & 25 & 75.8 \\
Not accessible & $\mathbf{3 3}$ & 24.2 \\
\hline Total & $\mathbf{1 0 0}$ \\
\hline The study involved an investigation on the credit accessibility of financial institutions by \\
gathering the respondents' perception. The feedback is indicated in Table 5. As per the \\
perceptions of 75\% of the respondents, CRB are perceived to make credit accessible to \\
borrowers. These findings is in agreement with Barron and Staten (2008) who in their work \\
confirms that through sharing of the credit information, the lenders are able to distinguish bad \\
borrowers from good borrowers in the market. This access to information helps lenders measure \\
borrower risk more accurately and to set loan terms and conditions accordingly. After evaluating \\
the reports, good borrowers with low risk are given more attractive prices, stimulating credit \\
demand, and fewer higher-risk borrowers would be rationed out of the market because of lenders \\
inability to offer these borrowers accommodating rates.
\end{tabular}




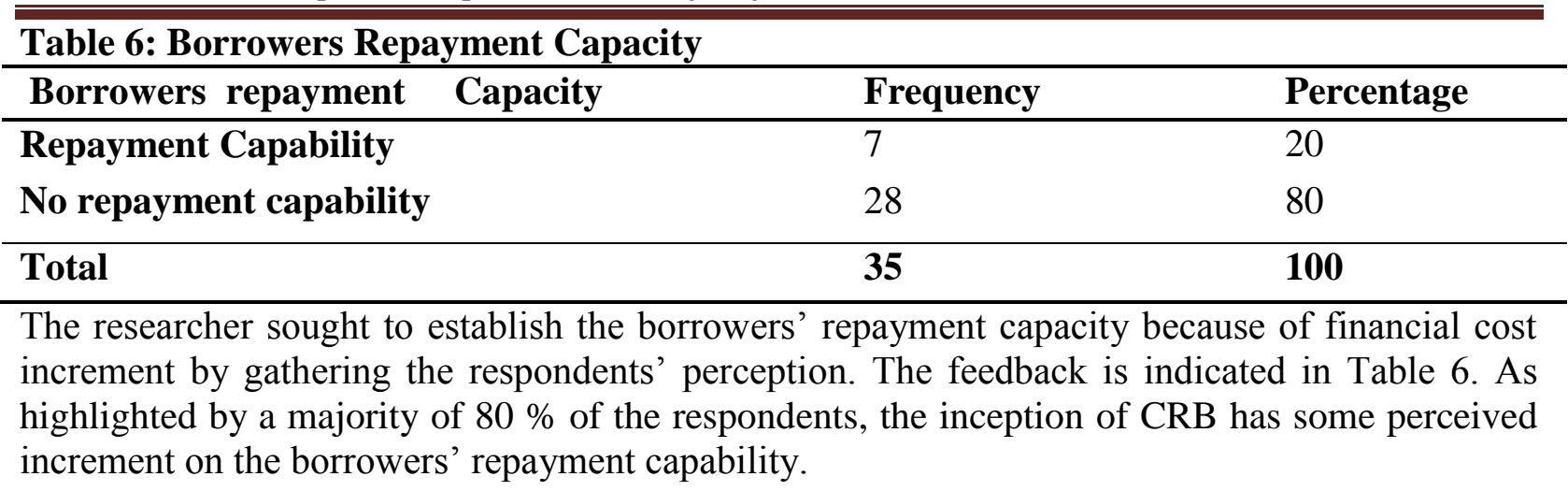

Table 7: Perceived Effects of CRB on Credit Access

\section{Opinions}

\section{Percent}

\begin{tabular}{lllll}
\hline $\begin{array}{l}\text { Strongly } \\
\text { agree }\end{array}$ & Disagree & Neutral & Agree & $\begin{array}{l}\text { Strongly } \\
\text { disagree }\end{array}$ \\
2.9 & 0 & 8.6 & 40.0 & 48.6 \\
2.9 & 0 & 2.9 & 62.9 & 31.4 \\
& & & & \\
5.7 & 2.9 & 17.1 & 42.9 & 31.4 \\
2.9 & 0 & 11.8 & 61.8 & 23.5 \\
2.9 & 2.9 & 8.6 & 62.9 & 22.9 \\
2.9 & 8.6 & 51.4 & 25.7 & 11.4 \\
3.0 & 6.1 & 21.2 & 54.5 & 15.2 \\
18.8 & 21.9 & 25.0 & 28.1 & 6.3 \\
25.7 & 28.6 & 17.1 & 25.7 & 2.9 \\
8.8 & 5.9 & 17.6 & 50.0 & 17.6 \\
2.9 & 8.8 & 5.9 & 47.1 & 35.3 \\
11.4 & 11.4 & 20.0 & 34.3 & 22.9 \\
\hline
\end{tabular}

The researcher went ahead to establish the respondents opinion on the CRB effects on credit access by financial institutions through a series of a 5 Likert -Scale questions whose response was categorized into Strongly Agree, Agree, Neutral, disagree and Strongly Disagree. The results are presented in Table 7. The study findings establishes that majority of the respondents (88.6\%) were of the opinion that CRB prevent serial loan defaulters from accessing credits from other financial institutions. The study shares the same remark as that of Sinare (2008) who investigated CRB in Tanzania and better environment for lenders and borrowers and revealed that CRBs play an important role in preventing serial loan defaulters from accessing credits from other financial institutions thus cushioning financial institutions against unforeseen credit risks. 
It is also evident from the study that a majority of $94.2 \%$ among the respondents pointed out that CRB provides reliable and inexpensive system to exchange information on the character and ability to pay of borrowers. This is harmony with Greuning (2003) who postulates that CRBs help lenders make faster and more accurate credit decisions making lending markets more competitive and, in the end, more affordable. This is facilitated by their role in collecting, managing and disseminating customer information to lenders within a provided regulatory framework. Credit histories not only provide necessary input for credit underwriting, but also allow borrowers to take their credit history from one financial institution to another. CRB was considered by a proportion of $74.3 \%$ of the respondents to have reduced cases of multiple borrowing. This is agreement with the findings of several scholars, Jappelli and Pagano (2000) as well as Bizer and Peter(2005), that stipulated clearly that multiple loan contracting, in which borrowers may obtain more advantageous credit terms through taking hidden loans from different lenders, with each lender possessing information over only his own contract with a borrower. Hidden loan contracts impose a negative externality because the unseen debt increases the probability of default on each loan. The same remarks on growing problem of multiple loan contracting has been well documented, for example, in Turkey (Kaynak and Harcar, 2001), South Africa (Daniels, 2004), and Central America (McIntosh and Wydick, 2005). Through the CRB report, lenders are in a position to identify the financial burdens or responsibilities of their borrowers as well as their commitment and capability of fulfilling them. CRB was considered to offer financial institutions access to databases that capture relevant aspects of clients' borrowing behavior by majority $(85.3 \%)$ of the respondents. The information according to majority of the respondents (85.8\%) CRB were found to provide credit reports with information that is relevant, complete, accurate and recent. This conquers with Nga'nga (2011) who consider Credit Reference Bureau as a company that collects information from various sources and provides consumer credit information on individual consumers for a variety of uses that entails detailed information on a person's credit history, including information on their identity, credit accounts and loans, bankruptcies and late payments and recent inquiries. Other information shared include: proven frauds and forgeries, cheque kiting, false declarations and statements, receiverships, bankruptcies and liquidations, credit default and late payments, use of false securities, and misapplication of borrowed funds. Prospective lenders access the information only when they have permissible reason as defined in law, to determine the borrower's creditworthiness. The study as indicated by $37.1 \%$ of the respondents sums up that CRB incorporate credit investigation and background checks providing what $69.7 \%$ of the respondents consider to be up to date borrower credit information, has significantly reduced cases of nonperforming loans. This is considered important according to Brown and Gregory (2007) who found empirical evidence that the lending market would collapse without CRB due to credit risk in the absence of information sharing institution and reputational banking. Their study also showed that establishing credit reference bureaus encouraged borrowers to repay their loans by allowing lenders to identify borrowers with a good payment history.The study revealed that CRBs provision of up to date borrower credit information, has significantly reduced cases of nonperforming loans according to $69.4 \%$ of the respondents. This is in line with Anderson (2007) who implied that credit sharing institutions, by documenting borrower behavior, positively impact borrower repayment and reduces NPLs.

Through the CRB reports, the financial institutions are in a position to access critical information on the borrower's income background as indicated by $34.4 \%$. This is in agreement with the 
findings of Kallberg and Udell (2003) who argues that most of the loan applicants have applied for and received loans they could barely afford. For instance, homebuyers need to spend money on buying furniture and getting their house in order and hence get themselves into large amounts of unsecured, high interest debt. According to their study, a combination of credit cards, personal loans and a loss of an income can be devastating for a dual income family, information considered very difficult to document as indicated by a big proportion of the respondents stating that even CRB is not able to provide information about borrower's living costs.

As far as the historic credit background information of the borrowers, a majority of $66.7 \%$ of the respondents agreed that CRB provides information about borrower's existing loan repayments. This is in agreement with Kevin (2010) who highlighted that whenever borrowers fail to repay their loans, banks are forced to pass on the cost of defaults to other customers through increased interest rates and other fees. Put simply good borrowers are paying for bad. Credit reporting allows banks to better distinguish between good and bad borrowers. The disclosure of credit reports through the $\mathrm{CRB}$ ensures that there is reduction in cases of multiple borrowing as stated by majority of the respondents (82.4\%) as well as cases of over indebtness according to $57.2 \%$ of the respondents. This is in agreement with Ngigi (2012) points out that among the benefit of the establishment of CRB services in any financial system facilitates the sharing of multiple borrowing and over-indebtedness of the borrowers that increases loan default unless the financial institutions have access to databases that capture relevant aspects of clients' borrowing behavior.

\subsection{Inferential Statistical Analysis}

The researcher conducted inferential statistical tests that comprised of correlation, regression and Chi-square analysis in an attempt to prove or disapprove the set of hypotheses that were formulated from the study objectives.

Table 8: Karl Pearson Correlation of role of CRB on influencing credit access and CDR

\begin{tabular}{lll}
\hline & & CA \\
\hline \multirow{2}{*}{ Karl Pearson Correlation (r) } & CDR & 0.316 \\
& CA & 1 \\
\hline \multirow{2}{*}{$\boldsymbol{p}$-value } & CDR & 0.00 \\
& CA &. \\
\hline
\end{tabular}

The results as indicated in Table 8, for Credit Access and Credit Default Rate, the coefficient of correlation was $\mathrm{r}(35)=0.316, \mathrm{p}=0.00<0.05$. This implies that the variables have a positive relationship that is significant at $5 \%$ levels of significance.

Table 9: Regression ANOVA

\begin{tabular}{|ll|l|l|l|l|l|}
\hline Model & & Sum of Squares & Df & Mean Square & F & Sig. \\
\hline \multirow{4}{*}{1} & Regression & 955.093 & 1 & 955.093 & 4.455 & $.042^{\mathrm{b}}$ \\
& Residual & 7074.749 & 33 & 214.386 & & \\
& Total & 8029.841 & 34 & & & \\
\hline
\end{tabular}

a. Dependent Variable: CRD

b. Predictors: (Constant), CA 
The researcher conducted further inferential statistical test using regression analysis so as explain the influence Credit Access (CA) on Credit Default Rate (CDR). First the data was tested to determine its suitability for regression analysis as explained by the ANOVA in table 9. Since the p-value $=0.04<0.05$ as displayed in the Regression ANOVA, this implies that regression analysis at $5 \%$ levels of significance is applicable for the study.

Table 10: Model Summary

\begin{tabular}{|l|l|l|l|l|l|}
\hline Model & $\mathrm{R}$ & $\mathrm{R}$ Square & $\begin{array}{l}\text { Adjusted } \\
\text { Square }\end{array}$ & $\begin{array}{l}\text { Std. Error of the } \\
\text { Estimate }\end{array}$ & Durbin-Watson \\
\hline 1 & $.345^{\mathrm{a}}$ & .119 & .092 & 14.64194 & 1.939 \\
\hline
\end{tabular}

a. Predictors: (Constant), CA

b. Dependent Variable: CDR

Model summary in Table 10 explains the influence of Credit access on Credit Default Rate. According to R-Square value $=0.119$ as presented in Table 10, the effect of Credit Access (CA), recorded a total of $11.9 \%$ of the dependent variable that is Credit Default Rate (CDR) with the rest proportion explained by extraneous variables as well as the error term.

\section{Table 11: Regression Coefficients}

\begin{tabular}{lll} 
& Unstandardized Coefficients (B) & $\boldsymbol{p}$-value \\
\hline (Constant) & -0.256 & 0.708 \\
CA & 0.337 & 0.024 \\
\hline
\end{tabular}

a Dependent Variable: CDR

The regression coefficients as displayed in Table 11 above were used to construct the regression model below. From the model below, the constant value was found to be -0.256 .

$\mathrm{CDR}=\mathbf{- 0 . 2 5 6}+\mathbf{0 . 3 3 7} \mathrm{CA}$

As for Credit Access and Credit Default Rate, the coefficient of correlation was 0.337, $\mathrm{p}=0.024>0.05$. This implies that the variables have a positive relationship that is significant at $5 \%$ levels of significance.

Table 12: Chi-Square Analysis on the Influence of CRB on Credit Default Rates

\begin{tabular}{llll}
\hline Determinants & Pearson Chi-Square & Degrees of Freedom & $\boldsymbol{p}$-value \\
\hline CA & 32.57 & 16 & 0.000 \\
\hline
\end{tabular}

Further tests were conducted for confirmatory purposes using Chi-Square analysis. The results of the Pearson Chi-Square Values, degrees of freedom and p-value at 95\% levels of confidence are presented in Table 12. As indicated in Table 12 above, The influence of Credit Access on Credit Default Rates yielded a $\chi(16, \mathrm{~N}=35)=32.57, \mathrm{p}=0.00<0.05$. This implies that its influence is significant at $5 \%$ levels of significance. 


\section{CONCLUSION}

The relationship between rate of credit access and credit default rate mitigation for commercial banks in Kenya yielded a coefficient correlation of $\mathrm{r}(35)=0.316, \mathrm{p}=0.00<0.05$. The regression analysis gave a coefficient of $0.337, \mathrm{p}=0.024>0.05$. While the Chi-Square recorded $\chi(16, \mathrm{~N}=$ $35)=32.57, \mathrm{p}=0.00<0.05$. All the tests were done at $5 \%$ levels of significance. This led to the rejection of the null hypothesis that states; CRB does not have a significant influence on credit access in mitigating against credit default in commercial banks in Kenya and the acceptance of the hypothesis that states; CRB has a significant influence on credit access in mitigating against credit default in commercial banks in Kenya. The researcher therefore concluded that the CRB plays a significant role in credit access in mitigating against default rate in commercial banks in Kenya at $5 \%$ levels of significance.

\section{REFERENCE}

[1] Ahmad, N. H. and Ariff, M. (2007). Multi-Country Study of Bank Credit Risk Determinants, International Journal of Banking and Finance, 5(1): 135-152.

[2] Ahmed, A. S., Takeda, C. and Shawn, T. (1998). Bank Loan Loss Provision: A Reexamination of Capital Management and Signaling Effects, Working Paper, Department of Accounting, Syracuse University, 1-37.

[3] Al-Khouri, R. (2011). Assessing the Risk and Performance of the GCC Banking Sector, International Journal of Finance and Economics, 65: 72-8.

[4] Allen, F., Santomero A., (1998). The Theory of Financial Intermediation. Journal of Banking and Finance and Public Management, 21: 1461-1485.

[5] Auronen, L. (2003). Asymmetric Information: Theory and Applications. Paper presented in the Seminar of Strategy and International Business as Helsinki University of Technology, May 21st 2003.

[6] Barron, J. M., \& Staten, M. (2003). The value of comprehensive credit reports: Lessons from the US experience. Credit reporting systems and the international economy, 8, 273-310.

[7] Berger, A. and Frame, S. (2005). Small business credit scoring and credit availability. The Journal of Banking and Finance

[8] Bizer, D.S. \& Peter, M. D.(1992).Sequential Banking.Journal of Political Economy, 100(1): 41-61.

[9] Brown, M., Tullio, J \& Marco P. (2007). "Information Sharing and Credit: Firm-Level Evidence from Transition Economies." Center for Studies in Economics and Finance Working Paper 178.by Financial Intermediaries: A dissertation presented in partial fulfillment of the Requirements for the Degree of Doctor of Philosophy in the Graduate School of the Ohio State University 2003

[10] CBK (2010). Kenya Licenses the First Credit Reference Bureau - Credit Reference Bureau Africa Limited (CRB Africa). Press release.

[11] Collins, N.J., \& Wanjau, K. (2011).The Effects of Interest Rate Spread on the Level of Non-Performing Assets: A Case of Commercial Banks in Kenya, International Journal of Business and Public Management 1(1).

[12] Daniels, R. (2004). Financial Intermediation, Regulation and the Formal Microcredit Sector in South Africa. Development South Africa, 21(4): 831-49.

[13] Derban, W.K., Binner, J.M. \& Mullineux, A. (2005).Loan repayment performance in community development finance institutions in the UK, Small Business Economics, 25: 319-32.

[14] Diamond, D., Rajan R., (2001). Liquidity risk, creation and financial fragility: A theory of banking. Journal of Political Economy, 2: 287-327.

[15] Djankov S., McLiesh C., \& Shleifer A., (2005). Private Credit in 129 Countries, NBER Working Paper 11078 (Cambridge, Massachusetts: National Bureau for Economic Research).

[16] Donaldson, T.H. (1994). Credit Control in Boom and Recession, The Macmillan Press: Basingstoke.

[17] Drehman, M., Sorensen, S. \& Stringa, M. (2008). The Integrated Impact of Credit and Interest Rate Risk on Banks: An Economic Value and Capital Adequacy Perspective, Bank of England Working Paper No.339. Economic Research Consortium, Research Paper 106.

[18]Epure, M. \& Lafuente, I. (2012).Monitoring Bank Performance in the Presence of Risk, Barcelona GSE Working Paper Series No.61. 
[19] Ferretti, F.F. (2006). Re-thinking the regulatory environment of credit reporting: Could legislation stem privacy and discrimination concerns? Journal of Financial Regulation and Compliance, 14 (3): 254 - 272.

[20] Fuser, K., Gleiner, W. \& Meier, G. (1999). Risk management - Erfahrungenaus der Praxis, Der Betrieb, 52(15): 753-758.

[21] Gaitho, N. (2010). The role of credit reference bureau on credit access, a survey of commercial banks in Kenya. Unpublished MBA Project. University of Nairobi.

[22] Gieseche, K. (2004). Credit Risk Modeling and Valuation: An Introduction, Credit Risk: Models and Management, Vol.2, Cornell University, London.

[23] Greuning, H., \& Bratanovic, S.B. (2003), Analyzing and Managing Banking Risk: A Framework for Assessing Corporate Governance and Financial Risk, 2nd ed., The World Bank, Washington, DC.

[24] Heffernan, S. (1996).Modern Banking in Theory and Practice, Wiley: New York.

[25]Hoff, K., \& Joseph S. (1998). "Moneylenders and Bankers: Price-Increasing Subsidies in a Monopolistically Competitive Market." Journal of Development Economics 55: 485-518.

[26] Holden, J.M. (1985). The Law and Practice of Banking (Volume 2): Securities for Bankers' Advances.

[27] Hoque, M, Z. (2009). Flawed working capital loan policy and loan default: Evidences from Bangladesh, Journal of Accounting, Business and Management, 11(2): 202- 213.

[28] IAIS - International Association of Insurance Supervisors (2003), paper on Credit Risk Transfer between Insurance, Banking and Other Financial Sectors, March. Italy Research Department,

[29] Rome.Jappelli, T., \& Marco, P. (1993).Information sharing in credit markets, Journal of Finance.45 (2).1719.

[30] Jappelli, T.\& Marco P. (1993). Information Sharing in Credit Markets. Journal of Finance.48 (5):16931718.

[31] Jappelli, T.\& Marco P. (2000). "Information Sharing in Credit Markets: A Survey." University of Salerno: CSEF Working Paper no. 36.

[32] Jappelli, T. and Pagano, M. (2002): Information sharing, lending and defaults: Cross-country evidence, Journal of Banking \& Finance, 5(3): 19-27.

[33] Jappelli, Tullio, and Marco Pagano, 'information Sharing, Lending and Defaults: Cross-CountryEvidence', (2002) 26 (10) (October) Journal of Banking and Finance 2017-2045.

[34] Kallberg, J. G., \& Udell, G. F. (2003).The value of private sector credit information, Journal of Banking and Finance and Institutional Economics, 2(1): 45-65

[35] Kargi, H. S. (2011). Credit Risk and the Performance of Nigerian Banks, Ahmadu Bello University, Zaria.

[36] Kaynak, E.\&Harcar, T. (2001).Consumers' Attitudes and Intentions Toward Credit Card Usage in an Advanced Developing Country. Journal of Financial Services Marketing, 6(1): 24-39.

[37] Kevin, G. \& Tiffany, G. (2010). Forecasting non-performing loans in Barbados: Business, Finance \& Economics in Emerging Economies vol. 5.

[38] Kithinji, A. and Waweru, N. M. (2007). Merger restructuring and financial performance of commercial banks in Kenya: Economic, Management and Financial Markets Journal.

[39] Kithinji, A. M. (2010). Credit Risk Management and Profitability of Commercial Banks in Kenya, School of Business, University of Nairobi, Nairobi.

[40]Leonard, K. J. (1995). The development of credit scoring quality measures for consumer credit applications. International Journal of Quality \& Reliability Management, 12(4): 79 - 8558

[41] McIntosh, C. \& Bruce, W. (2005).Competition and Microfinance. Journal of Development Economics, 78: 271-98.

[42] Mugenda, Olive M. and Abel G. Mugenda, (2003) Research Methods: Quantitative \& Qualitative Approaches.Nairobi.Acts Press.

[43] Mumi, S.M. (2010). The Impact of Credit Reference Bureau in Financial Institutions. School of Business, University of Nairobi, Nairobi.

[44] Nalukenge, I.K. (2003). Impact of Lending Relationships on Transaction Costs Incurred by Financial Intermediaries: A dissertation presented in partial fulfillment of the Requirements for The Degree of Doctor of Philosophy in the Graduate School of The Ohio State University 2003.

[45] Nganga, M.M. (2011). A study on stakeholder perception of credit reference bureau service in Kenya Credit Market. Unpublished MBA Project. University of Nairobi.

[46] Ngugi, R.W. (2001). An Empirical Analysis of Interest Rate Spread in Kenya.African Economic Research Consortium, Research Paper 106. 
DOI : https://dx.doi.org/10.26808/rs.rm.i6v7.01

International Journal of Research in Management

ISSN 2249-5908

Available online on http://www.rspublication.com/ijrm/ijrm_index.htm Issue 7, Vol. 6 (October-November 2017)

[47] Sinare, E.H. (2008). Credit Reference Bureau in Tanzania and Better Environment for Lenders and Borrowers. World Service Group Sullivan.

[48] Stieglitz, J. E., \& Weiss, A. (1981).Credit rationing in markets with imperfect information. The American economic review, 71(3), 393-410. 